\title{
Effects of Extracts of Feed Additives Including Rosemary (Rosmarinus officinalis) and Aloe Vera (Aloe barbadensis) on the Growth Performance and Feed Utility of Nile Tilapia (Oreochromis niloticus)
}

\author{
Ebru Yilmaz ${ }^{1, a, *}$, Deniz Çoban ${ }^{2, b}$, Birsen Kirim²,c ${ }^{2,}$ Mehmet Gülerº,d \\ ${ }^{1}$ Bozdoğan Vocational School, Aydın Adnan Menderes University, 09760 Bozdoğan/Aydın, Turkey \\ ${ }^{2}$ Department of Aquaculture, Faculty of Aqriculture, Aydın Adnan Menderes University, 09010 Efeler/Aydin, Turkey
}

${ }^{*}$ Corresponding author

\begin{tabular}{l|l}
\hline A R T I C L E I N F O & A B S T R A C T \\
\hline $\begin{array}{l}\text { Research Article } \\
\text { Received : 22/01/2019 }\end{array}$ & $\begin{array}{l}\text { This study was performed to determine the effects of the extracts of two alternative antimicrobial } \\
\text { agents that do not harm the ecosystem (rosemary, Rosmarinus officinalis and aloe vera, Aloe } \\
\text { barbadensis) when added to the feed of tilapia (Oreochromis niloticus) on the growth performance, } \\
\text { proximate composition, and biometric characteristics. Rosemary extract was added to the } \\
\text { experimental diet in ratios of } 0.1 \%, 0.25 \%, \text { and } 0.5 \% \text { while aloe vera extract was added to the } \\
\text { experimental diet in ratios of } 0.5 \%, 1 \%, \text { and } 2.5 \% \text {. After } 90 \text { days of the feeding trial, no change was } \\
\text { seen in the weight increase, specific growth rate, feed conversion ratio, condition factor, } \\
\text { hepatosomatic index, or viscerosomatic index of the tilapia. The fact that proximate analyses did not } \\
\text { differ between groups showed that the plant extracts did not adversely affect the health status of } \\
\text { tilapia in the ratios used in this study. As a result, the addition of } 0.1 \%, 0.25 \%, \text { and } 0.5 \% \text { rosemary } \\
\text { extract and the addition of } 0.5 \%, 1 \%, \text { and } 2.5 \% \text { aloe vera extract to tilapia feeds did not cause } \\
\text { changes in the growth performance, biometric indexes, or chemical composition findings of the fish } \\
\text { meat. }\end{array}$ \\
$\begin{array}{l}\text { Keywords: } \\
\text { Rosemary } \\
\text { Aloe vera } \\
\text { Tilapia } \\
\text { Growth performance } \\
\text { Feed utility }\end{array}$ & \begin{tabular}{l} 
and \\
\hline
\end{tabular}
\end{tabular}

Türk Tarım - Gıda Bilim ve Teknoloji Dergisi 7(6): 866-870, 2019

\section{Biberiye (Rosmarinus officinalis) ve Aloe Vera (Aloe barbadensis) Ekstraktları Katkılı Yemlerin Nil Tilapyası (Oreochromis niloticus) Balıklarının Büyüme Performansı ve Yem Kullanımı Üzerine Etkilerinin Araştırılması}

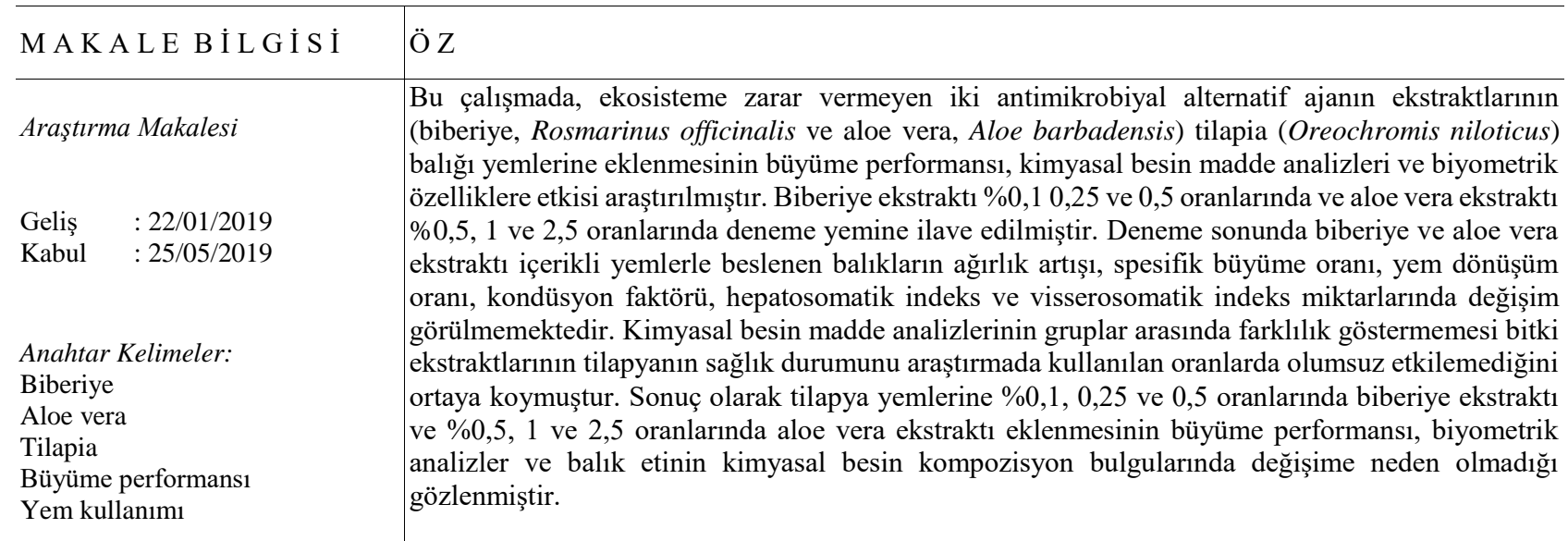




\section{Introduction}

The annual quantity of total tilapia and other cichlids obtained by aquaculture worldwide is 5,576,800 tons, accounting for $6.7 \%$ of the cultured animal-based aqua products with an economic value of USD 7,656,257,000 (FAO, 2015). The gradual increase in production through aquaculture in the world and intense production cause stress and diseases resulting in economic losses in addition to the increase of antibiotics and other chemicals that are not desired for the environment and consumers (Y1ldirım and Okumuş, 2004).

Antibiotics have been commonly used in the feeds of cultured fish for many years for the treatment of disease and for the increase of growth performance (Serrano, 2005). However, the use of antibiotics in the farming of fish and other animals is prohibited in many countries today (Ng and Koh, 2016).

Currently, it is necessary to evaluate alternative feed additives due to the restrictions on the use of antibiotics. Even for therapeutic purposes, the use of antibiotics increases the antibiotic resistance of bacteria. At the same time, problems arising from fish and the applications that fish are subjected to in different periods of farming have direct effects on production and operation economy (Ellis et al., 2002; North et al., 2006). Therefore, the addition of various additives as alternatives to synthetic products is currently being studied and this is a subject that requires further research. The addition of medicinal plants to fish feeds is a topic that has been recently studied in fish farming (Olusola, 2013).

There have also been various studies on the use of medicinal plants in relation to feed additives in aquaculture, growth, appetite, nutritional composition, immunity, larval growth, blood serum and hematology, and resistance to diseases, stress, bacteria, fungi, viruses, and parasites (Tafi et al., 2018; Stoyanova et al., 2018; Rahman et al., 2018; Panase et al., 2018; Panase and Tipdacho, 2018).

It is understood that medicinal plants are not sufficiently used in aquaculture in Turkey and that the suitable doses to be added to feeds have not been determined yet. In addition, it is currently necessary to determine in vivo effective doses of natural and reliable alternative antimicrobial agents that do not harm the ecosystem and to incorporate them into the sector. Rosemary (Rosmarinus officinalis) has antibacterial, antidiabetic, anticarcinogenic, antimicrobial, antiedema, antiviral, and antioxidant effects while aloe vera (Aloe barbadensis) has antiseptic and antioxidant effects (Ahmad et al., 2006; Poorfarid et al., 2013; Nwaoguikpe et al., 2010). In addition, rosemary is rich in carnosic and rosmarinic acid, compounds that were reported to have significant antioxidant features (Thorsen and Hildebrandt, 2003; Erkan, 2008). Rosemary increased the survival rate of tilapia infected with Streptococcus iniae by $25 \%$ (Abutbul et al., 2004).

Aloe vera plants contain large amounts of active compounds. These include aloesin, vitamins, enzymes, minerals, sugar, lignin, saponin, salicylic acid, and amino acids (Ajose, 2007). Aloe vera and rosemary plants have been studied in various fish species (Gabriel et al., 2015; Zilberg et al., 2010; Mahdavi et al., 2013; Tafi et al., 2018).
However, there is no current study on the extracts of these plants and tilapia. Therefore, the present study has been conducted to examine the effects of extracts of aloe vera and rosemary plants on the growth performance and feed use of tilapia.

\section{Materials and Methods}

\section{Fish and Experimental Design}

A total of 840 juvenile Nile tilapia fish (Oreochromis niloticus) were stocked with a stocking ratio of $40 \mathrm{fish} / \mathrm{tank}$ in 21 experimental aquariums $(40 \times 50 \times 100)$, the fish being of similar weights. The juvenile tilapia fish (average weight: $7.516 \pm 0.05 \mathrm{~g}$ ) used in this study were obtained from the Fisheries Faculty of Çukurova University and were not subject to any prior diseases. They were brought to the Aydin Adnan Menderes University Faculty of Aquaculture's Research and Application Unit, and relevant analyses were conducted in the TARBIYOMER Laboratory of the Aydin Adnan Menderes University Faculty of Agriculture. During the experimental period the water quality remained as follows: temperature, $24.01 \pm 0.11^{\circ} \mathrm{C} ; \mathrm{pH}, 7.09 \pm 0.39$; salinity, $0.5 \mathrm{ppt}$; total dissolved solids (TDS), $11.95 \mathrm{mg} / \mathrm{L}$; and dissolved oxygen, $8.01 \pm 0.37 \mathrm{mg} / \mathrm{L}$.

\section{Experimental Diet}

Rosemary extract and aloe vera extract were obtained from Talya Herbal Company, Turkey, and supplemented in tilapia diets at rates of $0.10 \%, 0.25 \%$, and $0.5 \%$ and $0.5 \%$, $1 \%$, and $2.5 \%$. These treatments were designated as R01, R025, R05, A05, A1, and A25 respectively. Previous studies were taken into consideration when selecting the usage rates of plant extracts (Gabriel et al., 2015; Mahdavi et al., 2013; Turan and Yiğitaslan, 2016). In the experiment, the rosemary and aloe vera extracts were added by spraying method after being solubilized in alcohol at ratios of $0.10 \%, 0.25 \%$, and $0.5 \%$ for rosemary and ratios of $0.5 \%, 1 \%$, and $2.5 \%$ for aloe vera. No plant extracts were added for the control group. Before the experiment, juvenile tilapia fish were divided into groups after 15 days of adaptation. The fish were fed twice a day at 08:00 and 16:00 hours for 90 days at $2 \%$ of their weight. The commercial diet (pellet size: $1 \mathrm{~mm}$ ) was obtained from Gümüşdoğa Feed Company (Table 1).

Table 1 Proximate analysis of the commercial diet (pellet size: $1 \mathrm{~mm}$ ) and extracts.

\begin{tabular}{l|l}
\hline \multicolumn{1}{c|}{ Nutrient } & \multicolumn{1}{c}{ Diet \% } \\
\hline Crude protein (\%) & 53 \\
Crude lipid (\%) & 15 \\
Crude cellulose (\%) & 0.9 \\
Crude ash (\%) & 11 \\
Compound & Rosemary extract \% \\
Rosmarinic acid & 5.32 \\
Compound & Aloe vera extract \% \\
Aloesin & 3.88 \\
\hline
\end{tabular}

Raw materials used in fish feed are fish meal, soybean meal, fish fat, wheat and byproducts, minerals, and vitamins. The ratios of phenolic compounds in the extracts of aloe vera and rosemary were obtained from Talya Herbal Company. 
Growth Performance and Biometric Indices

Calculations were conducted as follows for weight gain (WG), specific growth rate (SGR), feed conversion ratio (FCR), condition factor (CF), hepatosomatic index (HSI), and viscerosomatic index (VSI):

$$
\begin{aligned}
& \mathrm{WG}(\mathrm{g})=\mathrm{FW}(\mathrm{g})-\mathrm{IW}(\mathrm{g}) \\
& \operatorname{SGR}\left(\% \text { day }^{-1}\right)=\frac{(\mathrm{FW}(\mathrm{g})-\mathrm{IW}(\mathrm{g}))}{\text { Days }} \times 100 \\
& \mathrm{FCR}=\text { Feed intake }(\mathrm{g}) / \text { Weight gain }(\mathrm{g}) \\
& \mathrm{CF}=\text { Body weight }(\mathrm{g}) / \text { Total length }^{3} \times 100 \\
& \mathrm{HSI}=\frac{\mathrm{WWL}}{(\mathrm{WBW}-\mathrm{WWL})} \times 100
\end{aligned}
$$

WWL: Wet weight of liver $(\mathrm{g})$

WBW: Wet body weight (g)

$$
\mathrm{VSI}=\frac{\mathrm{WWVF}}{(\mathrm{WBW}-\mathrm{WWVF})} \times 100
$$

WWVF: wet weight of viscera and associated fat (g)

\section{Proximate Composition}

Proximate analyses were conducted using standard methods. Moisture analyses were conducted by drying the samples in order to fix a stable weight at $105^{\circ} \mathrm{C}$ for $24 \mathrm{~h}$ in an oven, crude protein was analyzed by the Kjeldahl method, and crude ash was dried by being burned at $525^{\circ} \mathrm{C}$ in a muffle furnace for $12 \mathrm{~h}$ (AOAC, 1998). The methanol chloroform extraction method was used to measure crude fat levels of the samples (Folch et al., 1957).

\section{Statistical Analysis}

The analyses of the data obtained in the experiment were done using the SPSS 17 statistics program. One-way analysis of variance (ANOVA) was applied to the data, which were then subjected to Tukey's multiple comparison test. The differences between groups were evaluated to be $\mathrm{P}<0.05$ (Logan, 2010).

\section{Ethics Statement}

Fish experiments were performed in accordance with the guidelines for fish research of the animal ethics committee at Aydın Adnan Menderes University (Project Number ADÜ BAP ZRF-17054).

\section{Results and Discussion}

Growth results are presented in Table 2. No particular difference was found in the final weight gain, FCR, SGR, $\mathrm{CF}$, HSI, or VSI $(\mathrm{P}>0.05)$.

Similarly, in the work of Golestan et al. (2015), the average initial weight of aloe vera extract did not affect the growth performance of $9.5 \mathrm{~g}$ of rainbow trout. In a different study, in rainbow trout with an average weight of $50.3 \mathrm{~g}$, it was determined that aloe vera added to feed in ratios of $0.1 \%$ and $1 \%$ increased SGR and reduced FCR (Heidarieh et al., 2013). It was observed in another study that SGR was increased and FCR was decreased by adding aloe vera extract in ratios of $0.1 \%, 0.5 \%$, and $2.5 \%$ to the feed of carp (Cyprinus carpio) with an average weight of $29 \mathrm{~g}$ (Mahdavi et al., 2013). Turan and Yiğitaslan (2016) reported that addition of rosemary extract in ratios of $0.25 \%$ and $0.5 \%$ to the feed of carp (Cyprinus carpio) resulted in a weight increase and decreased FCR. This difference may be related to the variance in the diets of carnivorous and omnivorous fish.

Excessive increase in condition factor is considered to be obesity while decrease is considered to be leanness (Timur, 2006). In other studies conducted with fish, it was seen that plants generally do not change the condition factor (Dügenci et al., 2003; Aly et al., 2008; Dakar et al., 2008). When green tea byproduct and a high ratio of black cumin $(2 \%)$ were used, the condition factor decreased (Cho et al., 2007; Diab et al., 2008). In these studies, there was no change in the condition factor with other forms of green tea use or the use of black cumin at a ratio of $1 \%$. These results show that the form and the ratio of some plants may adversely affect the condition factor. A mixture of different plants increased the condition factor in common sea bream (Ji et al., 2007).

The invariance in the VSI and HSI scores while the condition factor increased can be associated with the increase in meat mass. Similarly, Gabriel et al. (2015) found that there was no change in condition factor when tilapia was fed with aloe vera.

It is generally known that the liver of fish produced in aquaculture is too fatty and their color becomes lighter (Roberts, 2001). The excess fat from the feed is not used as energy by fish; rather, it is stored in the organs and tissues, which negatively affects the health of the fish and reduces the utilization of feed. As the amount of fat stored in the liver increases, the weight of the liver also increases, which can be detected by the HSI.

Table 2 Fish performance and feed utilization for tilapia fed diets containing different herbal extract supplements for 90 days.

\begin{tabular}{l|ccccccc}
\hline & Control & R01 & R025 & R05 & A05 & A1 & A25 \\
\hline IFW & $7.58 \pm 0.05$ & $7.51 \pm 0.05$ & $7.51 \pm 0.01$ & $7.48 \pm 0.06$ & $7.51 \pm 0.03$ & $7.48 \pm 0.02$ & $7.50 \pm 0.11$ \\
FFW & $23.57 \pm 0.05$ & $23.91 \pm 0.19$ & $23.87 \pm 0.40$ & $23.62 \pm 0.15$ & $23.66 \pm 0.10$ & $23.68 \pm 0.19$ & $23.88 \pm 0.03$ \\
WG & $15.98 \pm 0.08$ & $16.39 \pm 0.24$ & $16.35 \pm 0.40$ & $16.13 \pm 0.08$ & $16.14 \pm 0.07$ & $16.19 \pm 0.20$ & $16.37 \pm 0.12$ \\
CF & $1.28 \pm 0.00$ & $1.26 \pm 0.00$ & $1.28 \pm 0.03$ & $1.31 \pm 0.04$ & $1.33 \pm 0.00$ & $1.28 \pm 0.01$ & $1.30 \pm 0.01$ \\
FCR & $1.43 \pm 0.02$ & $1.42 \pm 0.00$ & $1.39 \pm 0.08$ & $1.37 \pm 0.09$ & $1.41 \pm 0.06$ & $1.40 \pm 0.08$ & $1.38 \pm 0.05$ \\
SGR (\%/day) & $1.02 \pm 0.00$ & $1.04 \pm 0.01$ & $1.04 \pm 0.01$ & $1.03 \pm 0.00$ & $1.03 \pm 0.00$ & $1.03 \pm 0.00$ & $1.04 \pm 0.01$ \\
HSI & $2.03 \pm 0.30$ & $1.71 \pm 0.19$ & $2.00 \pm 0.21$ & $1.88 \pm 0.93$ & $2.08 \pm 0.23$ & $2.04 \pm 0.22$ & $2.37 \pm 0.48$ \\
VSI & $12.01 \pm 1.42$ & $11.14 \pm 0.20$ & $12.39 \pm 1.63$ & $11.39 \pm 0.35$ & $12.38 \pm 1.63$ & $10.73 \pm 0.97$ & $11.18 \pm 0.06$ \\
\hline
\end{tabular}

IFW: Initial fish weight (g), F: Final fish weight (g), WG: Weight gain (g), Values are mean \pm SE $(n=6)$. 
In our study, it was determined that the herbal sources used did not affect the liver fat in the fish. Similarly, in a study by Cho (2011), fig extract, onion extract, and Indian fig were reported to be ineffective on liver fat amount and HSI. However, in a study with channel catfish, oregano (Origanum heracleoticum L.) was reported to reduce the values of HSI and VSI (Zheng et al., 2009). In the same study, the decrease in the rate of HSI in parallel to VSI may have been due to the reducing effect of oregano on liver fat. A reduction in HSI scores was achieved by the use of Quillaja saponin, Astragalus radix + Lonicera japonica, and green tea plants in different studies on fish (Francis et al., 2002; Zakes et al., 2008; Cho et al., 2007). In a similar study, increased HSI was observed when genetically improved farmed tilapia juveniles with an average weight of $4 \mathrm{~g}$ were fed with feed including $31.7 \%$ protein and $7.3 \%$ lipid and feed with aloe vera additives in ratios of $0.5 \%$,
$1 \%, 2 \%$, and $4 \%$ per kilogram while VSI was not changed (Gabriel et al., 2015). VSI, which includes all the internal organs, generally gives information about weight gain or loss. In our study, it was determined that aloe vera and rosemary extracts did not change the values of VSI in tilapia. Similarly, when 0.5-4 g/100 g of Rheum officinale extract was added to the feed of Cyprinus carpio with an average weight of $5.39 \mathrm{~g}$, HSI and VSI scores did not change. No significant change was observed in wholebody proximate composition in the control group or the experimental groups (Xie et al., 2008).

The whole-body proximate compositions of fish at the end of the our experiment are presented in Table 3 . There was no significant difference related to protein, lipid, ash, or moisture between the experimental groups and the control group.

Table 3 Whole-body proximate composition (\%) of tilapia fed diets with different levels of herbal extract supplements for 90 day.

\begin{tabular}{l|ccccccc}
\hline Composition (\%) & Control & R01 & R025 & R05 & A05 & A1 & A25 \\
\hline Crude protein & $17.13 \pm 2.06$ & $17.28 \pm 0.46$ & $16.93 \pm 0.37$ & $17.82 \pm 1.23$ & $17.94 \pm 0.62$ & $16.79 \pm 0.31$ & $16.19 \pm 0.24$ \\
Crude lipid & $2.84 \pm 0.89$ & $2.01 \pm 0.90$ & $2.48 \pm 0.90$ & $2.74 \pm 1.63$ & $2.62 \pm 0.28$ & $2.34 \pm 1.38$ & $3.81 \pm 0.19$ \\
Crude ash & $3.13 \pm 0.81$ & $3.64 \pm 0.70$ & $3.22 \pm 0.77$ & $3.10 \pm 0.74$ & $4.08 \pm 0.54$ & $3.33 \pm 0.71$ & $3.64 \pm 0.62$ \\
Moisture & $72.51 \pm 1.23$ & $73.42 \pm 1.69$ & $72.71 \pm 0.43$ & $71.37 \pm 0.93$ & $71.19 \pm 1.17$ & $71.63 \pm 1.07$ & $70.77 \pm 0.16$ \\
\hline
\end{tabular}

Values are mean $\pm \operatorname{SE}(n=6)$.

Similarly, when the rosemary was added to the feed of sea bass with an average weight of $20.43 \mathrm{~g}$, no significant change was observed in the whole-body proximate composition ( $p>0.05)$ (Y1lmaz et al., 2012). Gabriel et al. (2017) found in their study that aloe vera plant did not change the amount of moisture, ash, or lipid in tilapia juveniles, but it reduced the amount of protein. In light of all these studies, it is seen that plant sources, with the components they contain, make positive or negative changes in fish meat nutritional values. Therefore, the type of plant to be used is of great importance. It should be kept in mind that the same plant species may have different effects in different fish due to differences in fish species.

In conclusion, the present study indicates that after feeding Nile tilapia with a diet containing herbal extracts over a period of 90 days, it was found that rosemary and aloe vera extracts did not have any negative effect on the metabolism of the tilapia.

\section{Acknowledgments}

We would like to thank the Aydin Adnan Menderes University Research Fund for financial assistance (the project number ADÜ BAP ZRF-17054), and TARBIYOMER and KILIÇ Company for providing research facilities.

\section{References}

Abutbul S, Golan GA, Barazani O, Zilberg D. 2004. Use of Rosmarinus officinalis as a Treatment Against Streptococcus iniae in Tilapia (Oreochromis sp.). Aquaculture, 238: 97-105. DOI: 10.1016/j.aquaculture.2004.05.016.

Ahmad I, Agil F, Owais M. 2006. Modern Phytomedicine: Turning Medicinal Plants into Drugs. West-Sussex England: John Wiley and Sons. 405 p.
Ajose FO. 2007. Some Nigerian plants of dermatologic importance. Int J Dermatol., 1:48-55. DOI: 10.1111/j.13654632.2007.03466.x.

Aly S, Fathi M, John G. 2008. Echinaceaa as Immunostimulatory Agent in Nile Tilapia Oreochromis niloticus: via Earthen Pond Experiment. 8th International Symposium on Tilapia in Aquaculture. Cairo, Egypt, 1033-1042.

AOAC 1998. Official methods of analysis of AOAC International (16th ed., 4th Rev.). AOAC Int., Gaithersburg, MD.

Cho SH, Lee SM, Park BH, Ji S.C, Lee J, Bae J, Oh SY. 2007. Effect of Dietary Inclusion of Various Sources of Green Tea on Growth, Body Composition and Blok Chemistry of The Juvenile Olive Flounder, Paralichthys olivaceus. Fish Physiology and Biochemistry, 33: 49-57. DOI: 10.1007/s10695-006-9116-3.

Cho SH. 2011. Effects of Putative Growth or Health-Enhancing Dietary Additives on Juvenile Olive Flounder, Paralichthys olivaceus, Performance. Journal of the World Aquaculture Society, 42: 90-95. DOI: 10.1111/j.1749-7345.2010.00447.x.

Dakar AY, Hassanien GD, Gad SS, Sakr SE 2008. Use of Dried Basil Leaves as a Feeding Attractant for Hybrid Tilapia, Oreochromis niloticus X Oreochromis aureus, Fingerlings. Mediterranean Aquaculture Journal, 1(1): 35-44. DOI: 10.21608/maj.2008.2662.

Diab AS, Aly SM, John G, Abde-Hadi Y, Mohamed MF. 2008. Effect of Garlic, Black Seed and Biogen as Immunostimulants on the Growth and Survival of Nile Tilapia, Oreochromis niloticus (Teleostei: Cichlidae), and Their Response to Artificial Infection with Pseudomonas fluorescens. African Journal of Aquatic Science, 33: 63-68. DOI: 10.2989/AJAS.2007.33.1.7.391.

Dügenci SK, Arda N, Candan A. 2003. Some Medicinal Plants as Immunostimulant for Fish. Journal of Ethnopharmacology, 88: 99-106.DOI: 10.1016/S0378-8741(03)00182-X.

Ellis T, North B, Scott AP, Bromage NR, Porter M, Gadd D. 2002. The Relationships Between Stocking Density and Welfare in Farmed Rainbow Trout. Journal of Fish Biology, 61: 493-531. DOI: 10.1111/j.1095-8649.2002.tb00893.x. 
Erkan N, Ayranci G, Ayranci E. 2008. Antioxidant Activities of Rosemary (Rosmarinus officinalis L.) Extract, Blackseed (Nigella sativa L.) Essential Oil, Carnosic Acid, Rosmarinic Acid and Sesamol. Food Chemistry, 110: 76-82. DOI: 10.1016/j.foodchem.2008.01.058.

FAO, 2015. Total Fishery Production. Fishery Statistics. Fishstat Plus.

Folch J, Lees M, Sladane-Stanley GHA. 1957. Simple Method for the Isolation and Purification of Total Lipids from Animal Tissue. J. Biol. Chem., 226: 497-509.

Francis G, Makkar HPS, Becker K, 2002. Effects of Cyclic and Regular Feeding of a Quillaja Saponin Supplemented Diet on Growth and Metabolism of Common Carp (Cyprinus carpio L.). Fish Physiology and Biochemistry, 24: 343-350. DOI: 10.1023/A:1015047208108.

Gabriel NN, Qiang J , He J , Ma XY, Kpundeh MD , Xu P.2015. Dietary Aloe vera supplementation on growth performance, some haemato-biochemical parameters and disease resistance against Streptococcus iniae in tilapia (GIFT). Fish \& Shellfish Immunology, 44: 504-514. DOI: 10.1016/j.fsi.2015.03.002.

Gabriel NN, Qiang J, Ma XY, Xu P, Nakwaya DN. 2017. Effects of dietary Aloe vera crude extracts on digestive enzyme activities and muscle proximate composition of GIFT tilapia juveniles. South African Journal of Animal Science, 47:904913. DOI: 10.4314/sajas.v47i6.18.

Golestan G, Salati AP, Keyvanshokooh S, Zakeri M, Moradian H. 2015. Effect of dietary aloe vera on growth and lipid peroxidation indices in rainbow trout (Oncorhynchus mykiss). Veterinary Research Forum, 6:63 - 67.

Heidarieh M, Mirvaghefi RA, Sepahi A, Sheikhzadeh N, Shahbazfar AM, Akbari M. 2013. Effects of dietary Aloe vera on growth performance, skin and gastrointestinal morphology in rainbow trout (Oncorhynchus mykiss), Turkish Journal of Fisheries and Aquatic Sciences, 13:367-373. DOI: 10.4194/1303-2712-v13_2_20.

Ji SC, Takaoka O, Jeong GS, Lee SW, Ishimaru K, Seoka M, Takii K. 2007. Dietary Medicinal Herbs Improve Growth and Some Nonspecific Immunity of Red Sea Bream Pagrus major. Fisheries Science, 73: 63-69. DOI: 10.1111/j.14442906.2007.01302.x.

Logan M. 2010. Biostatistical design and analysis using r: a practical guide. Wiley-Blackwell, London. $546 \mathrm{p}$.

Mahdavi M, Hajimoradloo A, Ghorbani R. 2013. Effect of Aloe vera extract on growth parameters of common carp (Cyprinus carpio), World J Med Sci 9:55-60. DOI: 10.5829/idosi.wjms.2013.9.1.75128.

$\mathrm{Ng}$ WK, Koh CB. 2016. The Utilization and Mode of Action of Organic Acids in the Feeds of Cultured Aquatic Animals. Reviews in Aquaculture. 9:342-368. DOI: 10.1111 /raq.12141.

North BP, Turnbull JF, Ellis T, Porter MJ, Migaud H, Bron J, Bromage NR. 2006. The Impact of Stocking Density on the Welfare of Rainbow Trout (Oncorhynchus mykiss). Aquaculture, 255: 466-479. DOI: 10.1016/j.aquaculture .2006 .01 .004

Nwaoguikpe RN, W. Braide W, Ezejiofor TIN. 2010. The effect of Aloe vera plant (Aloe bardensis) extracts on sickle cell blood (hbss), African Journal of Food Science and Technology, 1:58-63.

Olusola SE, Emikpe BO, Olaifa FE. 2013. The potential of medicinal plant extracts as bio-antimicrobial in aquaculture. Int J Med Arom Plants, 3 (3): 404-412.

Panase P, Tipdacho P. 2018. Preliminary use of Polygonum minus Linn. leaf extract on growth performance, feed utilization, and some hematological indices of Anabas testudineus (Bloch, 1792). Comparative Clinical Pathology, 27:147-153. DOI 10.1007/s00580-017-2566-4.
Panase P, Khuangbun L, Suphason T, Tipdacho P. 2018. Evaluation of Houttuynia cordata Thunb. leaf extract on growth performance, feed utilization, and hematological indices of hybrid catfish (Clarias macrocephalus $\times$ Clarias gariepinus). Comparative Clinical Pathology, 27:947-958.

Poorfarid M, Karimi JH, Houshmand F. 2013. The effect of Aloe vera sap on progesterone, estrogen and gonadotropin in female rats. J Jahrom Univ Med Sci, 10:6-10.

Rahman AA, Khalil AA, Abdallah HM, ElHady M. 2018. The effects of the dietary supplementation of Echinacea purpurea extract and/or vitamin $\mathrm{C}$ on the intestinal histomorphology, phagocytic activity, and gene expression of the Nile tilapia, Fish \& Shellfish Immunology. 82: 312-318. DOI: 10.1016/j.fsi.2018.08.024.

Roberts RJ. 2001. Fish Pathology, 3rd Ed. WB Saunders Toronto. $472 \mathrm{p}$.

Serrano PH. 2005. Responsible use of Antibiotics in Aquaculture (No. 469). Food \& Agriculture Org.

Stoyanova S, Zhelyazkov G, Sirakov I, Velichkova K, Staykov Y. 2018. Influence of dietary cinnamomum verum extract on the growth and economic efficacy of common carp/cyprinus carpio 1. /, reared in a recirculation system. Trakia Journal of Sciences, 4:307-312. DOI:10.15547/tjs.2018.04.007.

Tafi AA, Meshkini S, Tukmechi A, Alishahi M, Noori F. 2018. Immunological and Antistreptococcal Effects of Salvia officinalis and Aloe vera Extracts Supplemented Feed in Rainbow Trout (Oncorhynchus mykiss), Kafkas Universitesi Veterinerlik Fakültesi Dergisi, 24: 365-370. DOI: 10.9775/kvfd.2017.18973.

Thorsen MA, Hildebrandt KS. 2003. Quantitative Determination of Phenolic Diterpenes in Rosemary Extracts Aspects of Accurate Quantification. Journal of Chromatography A, 995: 119-125. DOI: 10.1016/S0021-9673(03)00487-4.

Timur M., 2006. Balık Fizyolojisi (1. Baskı). Nobel Yayın Dağıtım, Ankara. 192 p.

Turan F, Yiğitarslan D. 2016. The Effects of Rosemary Extract (Rosemaria officinalis) as a Feed Additive on Growth and Whole-body Composition of the African Catfish (Clarias gariepinus (Burchell,1822)), Natural and Engineering Science, 1:49-55.

Xie J, Liu B, Zhou Q, Su Y, He Y, Pan L, Ge X, Xu P. 2008. Effects of Anthraquinone Extract from Rhubarb Rheum officinale Bail on the Crowding Stress Response and Growth of Common Carp Cyprinus carpio var. Jian. Aquaculture, 281: 5-11. DOI: 10.1016/j.aquaculture.2008.03.038.

Yıldırım Ö, Okumuş İ. 2004. Muğla Ilinde Su Ürünleri Yetiştiriciliği ve Türkiye Su Ürünleri Yetiştiriciliğindeki Yeri. E.Ü. Su Ürünleri Dergisi, 21: 361- 364.

Yılmaz S, Ergün S, Çelik EŞ. 2012. Effects of herbal supplements on growth performance of sea bass (Dicentrarchus labrax): Change in body composition and some blood parameters, J. BioSci. Biotech, 1: 217-222.

Zakes Z, Kowalska A, Zakes KD, Jeney G, Jeney Z. 2008. Effect of Two Medicinal Herbs (Astragalus radix and Lonicera japonica) on the Growth Performance and Body Composition of Juvenile Pikeperch (Sander lucioperca (L.)). Aquaculture Research, 39: 1149-1160. DOI: 10.1111/j.13652109.2008.01977.x.

Zheng ZL, Tan JYW, Liu HY, Zhou XH, Xiang X, Wang KY. 2009. Evaluation of Oregano Essential Oil (Origanum heracleoticum L.) on Growth, Antioxidant Effect and Resistance against Aeromonas hydrophila in Channel Catfish (Ictalurus punctatus). Aquaculture, 292: 214-218. DOI: 10.1016/j.aquaculture.2009.04.025.

Zilberg D, Tal A, Froyman N, Abutbul S, Dudai N, Goldhirsh AG. 2010. Dried Leaves of Rosmarinus officinalis as a Treatment for Streptococcosis in Tilapia. Journal of Fish Diseases, 33: 361-369. DOI: 10.1111/j.13652761.2009.01129.x. 